\title{
Gilberto Freyre e a intelligentsia salazarista em defesa do Império Colonial Português (1951 - 1974)
}

\author{
João Alberto da Costa PINTO•
}

\begin{abstract}
Resumo: Minha proposta, neste artigo, é analisar o percurso de Gilberto Freyre junto à intelligentsia salazarista, a partir de 1951, momento das redefinições estatutárias da administração colonial feitas por Salazar. E, junto a essas práticas governamentais, analisar também como o modelo teórico freyriano - o lusotropicalismo - foi apropriado como peça fundamental para que a justificativa ideológico-institucional em prol da manutenção do Império Colonial Português fosse internacionalizada.
\end{abstract}

Palavras-chave: Gilberto Freyre; Lusotropicalismo; Salazarismo.

O conjunto da obra de Gilberto Freyre, que soma mais de cinco dezenas de títulos, só pode ser abordado sob uma perspectiva totalizante. Essa maneira de ver me leva a considerar a hipótese de percorrer três roteiros internos de leitura - o regional, o nacional e o internacional -, cada qual tendo como epicentro o livro de 1933 - Casa Grande e Senzala - como particularidade dada. Cada roteiro afirma-se como uma leitura política específica projetada para o conjunto da obra. E, para uma descrição inicial, associo o conjunto de títulos que demarca a especificidade de cada um dos três roteiros. O primeiro está centrado numa interpretação da obra definida como politicamente marcada por temáticas de determinantes inflexões regionais (o conjunto bibliográfico que me possibilita essa assertiva escuda-se nos seguintes títulos: Casa Grande e Senzala (1933), Sobrados e Mocambos (1936), Nordeste (1937) e Na Bahia, em 1943 (1944)). O segundo movimento

\footnotetext{
- Professor Doutor - Faculdade de História - Universidade Federal de Goiás - UFG - 74001-970 - Goiânia - GO - Brasil. E-mail: joaoacpinto@yahoo.com.br
} 
interpretativo caracteriza uma proposição de inflexão nacional (o conjunto de referências que demarcam essa particularidade estaria centrado nos títulos: Casa Grande e Senzala (1933), Sobrados e Mocambos (1936), Quase Política (1950), Ordem e Progresso (1959), 6 Conferências em Busca de um Leitor (1965) e Rurbanização: Que é? (1982)). O terceiro movimento apoia-se naquilo que seria uma temática de inflexão internacional (o conjunto bibliográfico que possibilita esse movimento proposto é: Casa Grande e Senzala (1933), Interpretação do Brasil (1945), Aventura e Rotina (1953), Um Brasileiro em Terras Portuguesas (1953), Integração Portuguesa nos Trópicos (1958), Novo Mundo nos Trópicos (1959) e O Luso e o Trópico (1961)).

A imagem de pensador conservador está consagrada a Gilberto Freyre, autor de um livro revolucionário pela prodigiosa heurística que sugere, mas conservador pela visão de mundo que expressa. Quase sempre se fica nessa constatação. Sem dúvida Casa Grande e Senzala (1933) sintetiza, em grande parte, as questões fundamentais do conjunto do pensamento freyriano. Esse livro marca a abertura de um grande e complexo movimento conceitual, que o autor gestou ao longo de cinco décadas de intensa atividade intelectual, de grande repercussão internacional. Gilberto Freyre elaborou um vasto sistema interpretativo de evidentes consequências políticas no qual o personagem central sempre foi o Brasil.

$\mathrm{Na}$ sua proposta, procurou ampliar o sentido histórico estrutural do Brasil como região-líder de uma vasta e complexa cadeia de espaços inter-regionais, expressão síntese de uma totalidade geográfico-cultural definida como Trópico. Desse modo, Casa Grande e Senzala é o marco inaugural de um modelo explicativo originalíssimo que tinha como preocupação fundamental - principalmente nas décadas de 1950 e 1960 - a indagação de qual seria o lugar e o papel do Brasil no mundo. Um país visto como expressão e alternativa civilizacional à bipolaridade demarcada pelos blocos capitalista e socialista durante o processo da Guerra Fria (1947 - 1991).

Não cabe aqui discutir amplos significados do pensamento freyriano junto aos inúmeros estudos existentes sobre a sua 
obra. Contudo, de tudo que já se escreveu sobre a obra de Gilberto Freyre, o pequeno ensaio de Bastos (1986) parece-me a melhor síntese explicativa sobre o sentido teórico e político do conjunto da obra freyriana. Isso porque a autora não desnivela a obra do pensador pernambucano com juízos apriorísticos. Esse desnivelamento é facilmente encontrado em vários estudos ${ }^{1}$ que ressalvam, pela sua qualidade intrínseca, os livros de 1933 e 1936, e os demais são vistos apenas como afirmação publicística de um autor egocêntrico, ou - quando muito - meras inferências reacionárias no campo da geopolítica.

No estudo de Bastos, o lusotropicalismo surge no conjunto da obra como um corolário natural de inflexões sugeridas já em 1933; não seria, portanto, uma tese geopolítica reacionária proposta na década de 1950. Não que a autora compreenda o conjunto de trabalhos como uma somatória de propósitos teleológicos. Ao contrário, o que sugere é que na proposição política do intelectual (como sujeito transindividual), as perspectivas institucionais de um modelo explicativo vão se afirmando também como realidade política; logo, não há sentido em desqualificar um título da década de 1950 só porque poderia ser comparado como de inferior qualidade em relação ao livro de 1933. O que se impõe para todo e qualquer conjunto de análise historiográfica é a presença de uma perspectiva totalizante na abordagem.

Cada trajetória, cada conjunto de obra, apresenta, evidentemente, uma natureza intrínseca peculiar. Em Gilberto Freyre está presente um caráter uníssono na configuração conceitual de sua obra; bem como a prática política do intelectual ao longo da trajetória, que se agregou a inúmeros complexos institucionais. Assim, as bases conceituais de sua obra, mesmo sendo uníssonas - porque presumidas já na década de 1930, e sofrendo apenas algumas ampliações nas décadas seguintes - acabariam sendo recebidas politicamente de modo diferenciado, quase que divergente, pelos múltiplos aspectos das práticas político-institucionais do intelectual-autor. A interpelação política de Freyre imprimiu à sua obra e selou à sua trajetória uma forte marca esquerdista, tanto que foi eleito para o 
Congresso Constituinte nas eleições de 1946 pela UDN-PE, com expressivo apoio dos comunistas. Isso em decorrência da luta contra Agamenon Magalhães - quando este era o interventor de Getúlio Vargas em Pernambuco no Estado Novo (1937 a 1945). A magnitude de sua obra chegou ao arquipélago de Cabo Verde e deu sentido a um protonacionalismo anticolonialista frente ao domínio do colonialismo português; contudo, a mesma obra também acabaria por justificar as práticas do colonialismo salazarista (assunto deste artigo).

Portanto, é com essas indagações prévias que passo agora a apresentar alguns dos caminhos que o autor e o seu modelo teórico percorreram, tanto dentro quanto fora do Brasil. É fundamental ressalvar o caráter internacional da obra freyriana. Como procuro demonstrar nas páginas seguintes, nessa recepção internacional é que o autor melhor será referendado como um dos principais interlocutores da intelligentsia nacional diante dos debates sobre os destinos da Revolução Brasileira. A hipótese que demonstro se configura no percurso internacional do modelo teórico freyriano - percurso institucionalizado principalmente com o salazarismo, cumpre ressalvar -, é por causa dele que o autor se constituiu como um importante polo da intelligentsia nacional diante dos caminhos da organização da revolução capitalista brasileira. Sem a carreira internacional, Freyre jamais deixaria a sua província de ideias - Recife, Pernambuco, Nordeste - porque os quadros hegemônicos dessa intelligentsia centravam-se em São Paulo e no Rio de Janeiro, e sempre lhe foram refratários.

Outra variável, decorrente da carreira internacional de Freyre é a conquista da possibilidade, junto ao Estado brasileiro, de organizar um "feudo institucional" regional - o Instituto Joaquim Nabuco de Pesquisas Sociais, posteriormente nomeado como Fundação Joaquim Nabuco (aprovado como projeto seu, na Câmara Federal, quando foi deputado constituinte em 1946, pela UDN/PE). No final da década de 1950, esse Instituto já obtinha repercussão internacional - junto às instituições ideológicas salazaristas e ao governo norte-americano, por exemplo - e, com isso, viu-se reconhecido, garantindo-se como uma instituição 
regional fundamental nos marcos institucionais do Estado nacional, agregado ao Ministério da Educação e Cultura. As relações políticas da teoria lusotropicalista somariam ao "feudo institucional" a projeção e o reconhecimento intelectual internacional do modelo freyriano, inclusive muito além dos quadros do Estado salazarista. É o caso de vários intelectuais norte-americanos, da Fundação Ford, da Comissão Fulbright, além dos programas de governo do presidente John Kennedy, os quais organizavam o movimento pela Aliança Para o Progresso no começo da década de 1960. Tais programas obtiveram grande repercussão no Brasil e estiveram diretamente relacionados com as articulações do golpe militar de 31 de março de 1964.

Com a projeção do "feudo institucional", Gilberto Freyre também se articulou com os quadros da política regional pernambucana; isso significa que construiu seu reduto com base nas relações sociais que sempre mantivera com as oligarquias regionais - principalmente aquelas oriundas das tradicionais cercanias do latifúndio açucareiro. $\mathrm{Na}$ década de 1950, já consolidado o Instituto Joaquim Nabuco de Pesquisas Sociais, Gilberto Freyre - tido como a principal referência ideológica das tradicionais famílias dos engenhos de açúcar - conseguiu apresentar-se como referência ideológica hegemônica também das frações de classe do agrarismo mais "modernizante" - os usineiros. Freyre, consagrado regionalmente e internacionalmente, com o Instituto teria condições de lutar pela sua consagração nacional. O golpe de 1964 foi uma das faces dessa consagração. Com os acontecimentos associados a essa data e a intervenção política de Freyre ao lado das forças golpistas, o bloco agrário nordestino obteve ideologicamente o seu passaporte para a renovação do grande pacto das classes dominantes em torno da agenda política dos governos militares. Assim, a obra teórico-política de Gilberto Freyre conseguia ao longo do período (1930 - 1964) dar sobrevida ideológica a uma fração importante da classe dominante brasileira no século XX a burguesia agroindustrial nordestina -, que declinava politicamente nos estertores do seu solapamento produtivo diante dos moldes do capitalismo monopolista. O seu modelo 
seria também uma marca ideológico-estruturante da ação dos militares-gestores, a começar pelo próprio Marechal Humberto Castelo Branco.

Dessa maneira, é fundamental constatar que Gilberto Freyre construiu o seu caminho como quadro da intelligentsia nacional e como intelectual orgânico do latifúndio nordestino; e que sua palavra transfigurou-se no máximo de consciência possível do bloco agrário nordestino, constantemente ameaçado pela hegemonia industrialista da burguesia paulista. Gilberto Freyre consolidou esse caminho com o seu feudo-institucional (regional de classe); mas para chegar a essa condição - e isso independe de qualquer teleologismo meu - teve que enfrentar duras oposições políticas em Pernambuco, e depois se lançar às águas do Atlântico e construir os novos lusíadas de Portugal, melhor dizendo, afirmar o lusotropicalismo como um lusíada panglossiano de Salazar ${ }^{2}$.

\section{I}

Com o fim da Segunda Guerra Mundial, o regime fascista salazarista do Estado português obrigou-se a uma nova definição estatutária para a caracterização de suas colônias espalhadas pela África e pela Ásia. António de Oliveira Salazar sabia que, se não tomasse providências urgentes naquele momento de redefinição do desenho geopolítico internacional, os espaços coloniais portugueses poderiam sucumbir perante as novas concepções liberalizantes dos autonomismos nacionalistas (África e Ásia, principalmente). Essas concepções, formuladas na década de 1940, se consumariam como práticas políticas efetivas na década de 1950 até meados da década de $1970^{3}$.

Salazar, no controle efetivo do Estado português desde 1933, obrigou-se a novas práticas de gestão governamental para tentar assim recaracterizar o velho Império português. O Império das "glórias" camonianas dos séculos XVI e XVII seria permanentemente reabilitado pelo fascismo salazarista em pleno 
século XX. O Estado procurava a sua essência nas práticas "civilizadoras" da velha conquista colonial. Não buscava novas colônias, mas colonizar efetivamente aquelas que já lhe pertencia há séculos. A marca emblemática de refundação do colonialismo deu-se em 1933, por meio de um documento que se demarcaria como a carta constitucional do colonialismo português contemporâneo - o Acto Colonial. ${ }^{4}$ Nesse documento, sumariavam-se os conceitos e os gestos institucionais do Estado português, convergidos em premissas fortemente centralizadoras no que se refere à administração das colônias.

Com práticas de concessão - no jogo diplomático, sujeitando-se a interesses geopolíticos da Inglaterra e dos Estados Unidos (EUA) - o governo de Salazar conseguiu manter ao longo da Segunda Guerra Mundial as fronteiras do Império intactas. $\mathrm{E}$, diante dos novos tempos, que o pós-guerra impôs ao mundo, novamente Salazar esteve sob a contingência de novas concessões. Propôs mudanças formais na legislação da administração colonial para que tudo ficasse como estava.

Tais práticas conjunturais de manutenção estrutural do Império não eram, evidentemente, somente obras da vontade de Salazar. Para justificar "o mundo que o português criou", teve inúmeros parceiros intelectuais, com o apoio dos seus "cães de guarda" do Império ${ }^{5}$. Refiro-me a importantes intelectuais, que o assessoraram diretamente na condução dos negócios do Estado, ora como ministros, ora como chefes de centros de pesquisa, ou ainda como representantes diplomáticos junto à Organização das Nações Unidas - ONU. Faço referência a alguns nomes como o de Armindo Monteiro (foi Ministro do Ultramar); o de Adriano Moreira (membro da Junta de Investigações do Ultramar [JIU], criador do Centro de Estudos Políticos e Sociais [CEPS], pertencente à JIU e também Ministro do Ultramar); o de Sarmento Rodrigues (membro da Marinha [Comodoro] portuguesa e também Ministro dos Negócios Estrangeiros); e Franco Nogueira (diplomata, chefe da delegação portuguesa na ONU em meados da década de 1950 e ministro do Ultramar). Sobre Armindo Monteiro e Franco Nogueira, teço alguns comentários de passagem. Adriano Moreira e Sarmento 
Rodrigues terão aqui maior destaque porque são os responsáveis diretos pela presença institucional do lusotropicalismo de Gilberto Freyre junto às práticas reformistas de Salazar no pós-guerra.

Esses intelectuais tiveram um papel determinante na confecção do ideário político-institucional que se disseminou por todas as áreas no mundo de influência lusitana, principalmente nas décadas de 1950 e 1960. Ou seja, responsabilizavam-se, junto ao regime salazarista, pela busca do sentido e do significado de Portugal no mundo, num momento de crescentes tensões internacionais em que - na concorrência pelo domínio dos mercados mundiais - a geopolítica bipolar dos EUA e da União Soviética (URSS) se impunha. Salazar e seus ideólogos procuraram nesse contexto, uma alternativa que não transfigurasse a historicidade de Portugal no mundo e que não se subordinasse ao domínio de um dos polos hegemônicos a maior herança dessa historicidade - o Império Ultramarino. Salazar lutou contra a bipolaridade, não se dispôs a ficar ao lado dos EUA, foi um parceiro esquivo, arredio da política internacional desse país. Mas também foi francamente anticomunista com a URSS. Salazar e seus ideólogos apresentavam-se ao mundo, como antiliberais e anticomunistas, aspecto que demarcava o cariz essencialmente fascista do regime.

Por suas opções isolacionistas, o corporativismo do Estado salazarista pôs Portugal em rota econômica regressiva. E, por ironia, quando Portugal começou a ganhar economicamente com a exploração intensificada de suas colônias (anos 1960 - 1970), momento em que volta a participar efetivamente da economia internacional, seu Império veio abaixo. Em 1974, os sonhos da grandeza sofística foram desfeitos definitivamente.

Em 1951, o Acto Colonial de 1933 deixou de ser a marca constitucional diretiva das práticas institucionais do Estado português junto às colônias ultramarinas. Novas práticas administrativas foram sugeridas, dentre elas está o termo central de que as colônias que eram definidas como tais, naquele momento passariam a ser nomeadas como províncias 
ultramarinas. Mudava-se a terminologia, mas as práticas e as realidades permaneciam intocadas. Esse é o significado do fim do Acto Colonial. Mesmo não alterando substantivamente em nada a realidade do domínio imperial, ainda assim, o seu fim não foi apoiado de modo unânime. $\mathrm{Na}$ ocasião, Armindo Monteiro, um dos mais expressivos políticos portugueses do século $\mathrm{XX}$, que fora um dos principais articuladores do Acto Colonial, manifestou oposição intransigente à revogação daquele documento ${ }^{6}$. A intransigência de Armindo Monteiro dava-se por sua opinião contrária às tendências histónicas do mundo no pósguerra. Acreditava que Portugal, como país soberano, não deveria dar atenção às opiniões intemacionais. O gesto reformista de Salazar era apenas uma concessão retórica. Alteravam-se significados de palavras, mas não se alteravam as práticas colonialistas ${ }^{7}$.

Junto com a reforma constitucional que transformou retoricamente o estatuto administrativo das colônias do ultramar, o governo de Salazar mobilizou gigantesco esforço de propaganda para justificar internacionalmente uma nação de extensas fronteiras, que do Minho ao Timor faziam de Portugal um só território. É nesse momento crucial que a obra e o pensamento de Gilberto Freyre tornaram-se instrumentos da máquina de propaganda salazarista. $\mathrm{E}$ isso não aconteceu à revelia de Freyre, muito pelo contrário, ele aceitou de bom grado o papel de ideólogo salazarista e em alguns momentos foi percebido como um dos mais eficientes cães de guarda do Império ${ }^{8}$.

Em termos gerais, a conjuntura internacional do pós-guerra impunha ao Estado português o esforço gigantesco de cristalizar, em várias frentes, o sentido do seu Império no mundo. Em primeiro lugar, buscava-se na ONU o consenso de um Portugal com colônias, mas sem perceber-se colonialista daí as alterações constitucionais. Outro ponto era o consenso sobre o sentido dessa realidade histórica, isto é, buscava-se uma arquitetura teórica que justificasse a tradição do colonialismo lusitano ao longo do tempo, como uma estrutura histórica diferenciada daquela ocorrida em outros países colonialistas. E, em terceiro lugar, estava a necessidade de convencer a própria população de que tal engenharia administrativa seria de fato 
uma realidade operacional; bem como conseguir justificar ao mais simples lavrador português que as terras fecundas e ainda inexploradas da África eram também as terras do seu "querido" Portugal. Tal chamamento, derivado desse consenso, teve resultados significativos, pois na década de 1950 constatou-se um deslocamento considerável de portugueses metropolitanos para as duas principais colônias africanas - Angola e Moçambique. Em suma, três frentes de luta, três campos de intervenção ideológica que só poderiam ter-se sistematizado com uma complexa engenharia institucional organizada a partir do Estado.

Os principais espaços institucionais de articulação das reformas na esfera estatal foram: o Ministério dos Negócios Estrangeiros (MNE), o Ministério do Ultramar (MU), a Junta de Investigações do Ultramar (JIU) e o Instituto Superior de Estudos Ultramarinos (ISEU). Este último era a transfiguração, a partir de 1954, da Escola Superior Colonial que foi criada em 1927 e originada da primeira Escola Colonial que, por sua vez, foi fundada em anexo à Sociedade de Geografia em 1906. Justificar a perpetuação anacrônica das colônias num mundo cada vez mais hostil a práticas imperialistas e colonialistas era a função ideológica cumprida em conjunto pelos ministérios, como entidades políticas, pela JIU e pelo ISEU, como entidades de pesquisa.

Passaram pelos ministérios, entre outros, Sarmento Rodrigues - no início da década de 1950, e Adriano Moreira - no início da década de $1960^{\circ}$. O primeiro marcou sua gestão pela consolidação da imagem do Império. O segundo lutou em defesa (física, no combate às guerrilhas pró-independentistas da África) da perpetuação dessa imagem. Foi Sarmento Rodrigues quem convidou Gilberto Freyre para uma longa viagem de sete meses por todo o Império. Foi Adriano Moreira quem, a partir de 1961, organizou a feroz resistência armada das tropas portuguesas contra os primeiros levantes nacionalistas autonomistas - o caso específico ocorrido no Norte Angolano contra a guerrilha do Movimento Popular pela Libertação de Angola (MPLA) -; e quem instituiu nessa colônia as práticas repressivas da polícia secreta 
do Estado - a Polícia Internacional de Defesa do Estado (PIDE). Foi Sarmento Rodrigues quem apresentou a obra de Gilberto Freyre a Salazar e quem convenceu este da importância de Freyre para Portugal ${ }^{10}$. Foi durante a sua gestão ministerial que Adriano Moreira, em Moçambique, homenageou, entre tantas outras, a obra do pensador pernambucano como uma das maiores contribuições à cultura portuguesa em todos os tempos ${ }^{11}$.

A Junta de Investigações do Ultramar foi uma instituição emblemática das preocupações de Salazar com os novos tempos advindos com o pós-guerra. Surgiu em 1945 e era a transfiguração da antiga Comissão de Cartografia, criada em 1883. A Junta compunha-se de vários centros de estudo e institutos de pesquisa, os quais eram responsáveis pela articulação dos conhecimentos sociológicos, antropológicos e políticos dos povos e regióes ultramarinas. A JIU promoveu inúmeras atividades de pesquisa e várias missões de estudo às colônias, sempre com o sentido de justificar a singularidade civilizacional do homem português em regiões tropicais. Seu principal centro de pesquisa foi o Centro de Estudos Políticos e Sociais (CEPS), criado e dirigido em 1956 por Adriano Moreira (VENÂNCIO, 1996: 144-145). A participação de Adriano Moreira como ministro de Estado em 1961 deve-se, em grande parte à sua atuação como intelectual e político dentro do CEPS. Foi ali que o lusotropicalismo tornou-se uma factibilidade científica.

Alguns anos mais tarde, com as teses do lusotropicalismo já disseminadas, o CEPS de Adriano Moreira adotaria também o procedimento das excursões ao Império (Freyre organizaria o mesmo no Nordeste Brasileiro, com as missões de estudos do Instituto Joaquim Nabuco de Pesquisas Sociais, promovidas nas décadas de 1950 e 1960). Em 1957, o CEPS promoveu "três missões de estudo para a realização de inquéritos diretos nas províncias ultramarinas" (CASTELO, 1998: 103-105). Mas, ao contrário do que se esperava, nessas missões os pesquisadores acabaram por constatar o que lhes parecia impossível: os colonos portugueses eram racistas! Ainda assim, e mesmo com os fatos negando o modelo lusotropical de civilização, os 
pesquisadores do CEPS apontaram logo a solução: "a solução passa pela reeducação dos colonos que já vivem no território e pela seleção de futuros colonos" (CASTELO, 1998: 103-105). Os fatos calavam a mitologia.

Agora, no contexto da narrativa deste artigo, é o momento de apresentar uma definição mais sistemática do significado conceitual do lusotropicalismo, junto à obra de Freyre, destacando, para tanto, o seu trabalho de 1958 - Integração Portuguesa nos Trópicos ${ }^{12}$.

Gilberto Freyre afirma que Portugal teria iniciado no século XV "um novo tipo de civilização" por causa de seu caráter de expansão "singularmente simbiótico de união de europeu com trópico"; e "ao lado desse novo tipo de civilização vir-se-ia desenvolvendo um novo tipo de conhecimento ou saber dos trópicos pelo europeu, para o qual se sugere a caracterização de lusotropicologia" (FREYRE, 1960b: 69) ${ }^{13}$. Esse "novo" tipo de saber, que Freyre encontra na colonização lusa, "é um saber experimental" ${ }^{14}$. O saber de experiência, um tipo de empirismo pragmático, que Freyre afirma já estar presente em Camões. Esse saber, criado na simbiose do homem luso com os povos tropicais, deu origem a práticas fraternas de assimilação. Assimilação cultural e não etnocêntrica. Tais elementos haveriam de fundamentar o alvorecer de uma nova civilização. Assim afirma o autor sobre a civilização lusotropical:

- que denominamos 'civilização lusotropical' não é, biossocialmente considerada, senão isto: uma cultura e uma ordem social comuns à qual concorrem, pela interpenetração e acomodando-se a umas tantas uniformidades de comportamento do Europeu e do descendente e do continuado do Europeu nos trópicos - uniformidades fixadas pela experiência ou pela experimentação lusitana - homens e grupos de origens étnicas e 
de procedências culturais diversas. Vê-se assim que é um conceito, o sociológico, de civilização lusotropical, de cultura e de ordem social lusotropicais, que ultrapassa o apenas político ou retórico ou sentimental de 'comunidade luso-brasileira'. (FREYRE, 1960b: 74).

Após essa definição, o autor apresenta um corolário mistificador, quando afirma que "a adaptação lusitana aos trópicos vem sendo tão profunda que os próprios nativos das regiões quentes distinguem os Portugueses dos demais europeus. Sentem-se mais próximos deles" (FREYRE, 1960b: 95).

Com uma argumentação assim estruturada, percebe-se como não foi difícil para o Estado português incorporá-la à sua agenda de propaganda política. Não importava tanto a sustentação científica do argumento e a sua verificabilidade empírica (ainda mais quando as pesquisas comprovavam o contrário do proposto pelo modelo teórico). O que importavam eram as palavras escritas por um intelectual de reconhecimento mundial. O Estado salazarista utilizar-se-ia, antes de tudo, da autoridade intelectual já representada em torno de Gilberto Freyre ${ }^{15}$.

Pela vastidão e complexidade de sua obra, Gilberto Freyre tinha já na década de 1950, um grande reconhecimento internacional. Nenhum intelectual brasileiro fora tão longe nas láureas como as que Freyre recebeu - chegou a ser homenageado em 1967, para grande orgulho seu, com o título de Cavaleiro Comandante do Império (Sir) pela rainha da Inglaterra.

Dentre os elementos fundamentais que caracterizaram a celebração internacional de Freyre estava a reputação do livro Casa Grande e Senzala. O sucesso desta obra deu-se por seu caráter inovador da interpretação sociológica e historiográfica da formação do Brasil. Resumindo, o autor propunha com essa obra uma nova identidade ao povo brasileiro. Identidade essa que divergia frontalmente daquelas apresentadas pelos modelos racistas desenvolvidos na cultura brasileira na segunda metade do século XIX e nas duas primeiras décadas do século XX. O principal aspecto dessa renovação estava relacionado à questão 
racial e aos problemas do mestiçamento no Brasil. Se a tônica interpretativa do pensamento social que o precedeu sustentava a necessidade de um racismo científico para assim justificar-se socialmente a superioridade do homem branco na consolidação da civilização brasileira - uma tese importante é a de Oliveira Vianna, por exemplo - Gilberto Freyre subverteria essa equação apresentando um novo argumento: as possibilidades civilizacionais da integração racial. Na sua interpretação, o Brasil constituíra-se como racialmente mestiço e essa mestiçagem determinava-se como um elemento positivo. Esse seria o aspecto central de uma civilização tropical que se elaborava desde a colonização, no século XVI.

Para Gilberto Freyre, tanto o negro africano como o índio foram, no Brasil, elementos que civilizaram o branco português e este na sua "intrínseca" aclimatabilidade, no amalgamento inter-racial, logo deixou de ser português para tornar-se lusobrasileiro. O português para Freyre já era um mestiço em Portugal; dessa maneira, por essas condições inatas, jamais poderia se desenvolver historicamente um Brasil branco e europeu. Esse foi um dos termos centrais do lusotropicalismo. Dessa confluência inter-racial, inaugurou-se no Brasil, conforme o autor, um novo processo civilizatório que se estenderia a todos os espaços de colonização portuguesa. E para melhor justificar o sentido da instrumentalização do modelo explicativo freyriano pelo Estado salazarista, Casa Grande e Senzala sugere o português como herói colonizador, portador de um conjunto específico de práticas de colonização que o tornam único na experiência histórica das colonizações.

Por causa desse legado, o homem brasileiro, afirmou Freyre em seu livro Um Novo Mundo nos Trópicos, era crescentemente suprarracial, mais ainda porque

Inclui esse tipo supra-racial ou meta-racial de homem situado no trópico sua crescente morenidade que não exclui, entretanto, brasileiros de aspecto nórdico, louros e claros, da categoria de autênticos brasileiros. Inclui sua harmonização, também crescente, com a sua condição de 
homem situado principalmente numa ecologia tropical. (...) Há um tipo já nacional de homem brasileiro para o qual vêm convergindo vários subtipos regionais que podemos considerar básicos na formação - que ainda se processa desse tipo bio-sociocultural total. Esse tipo no seu aspecto biológico é menos uma síntese racial que uma síntese ultra-racial: uma meta-raça. Uma além-raça. (FREYRE, 1972: 323-324).

Após 1945, grande parte da obra freyriana tem uma direção: definir cientificamente esse processo de ineditismo civilizatório em formação no Brasil e nas demais regiões tropicais em que o português se firmou como colonizador. Ressalvo, então, algumas das principais demarcações conceituais do lusotropicalismo. O conceito de área total é fundamental. Junto a esse, impõe-se o de região. O autor afirmará que "o conjunto de regiões luso-tropicais (...) formam uma área total" (FREYRE, 1961: 42). Por "área total" designará o "conjunto de espaços tropicais hoje ocupados pela gente lusitana ou de origem principalmente lusitana ou portadora de cultura principalmente lusitana: conjunto do qual o Brasil se destaca como sua maior força atual" (FREYRE, 1961: 43). Entenda-se o caráter transnacional que é imanente à definição de área total.

Freyre acreditava que o termo transnacional esquivaria a pesquisa de eventuais preconceitos nacionais, o que poderia acontecer se ela estivesse determinada operacionalmente por um conceito como o de Estado ou o de Nação. Segundo Freyre, esses seriam conceitos restritivos que impediriam o acesso à perspectiva totalizante imanente ao objeto, no caso, a civilização inter-racial nascida no espaço de colonização portuguesa. A investigação, para se chegar a uma efetiva demarcação da área total, teria de ser iniciada junto às particularidades inerentes a cada uma das regiões dessa área total. $\mathrm{Na}$ análise do autor, o Brasil seria uma região dentro da área total - o trópico colonial português (e o Brasil como região, teria também dentro de si, 
regiões demarcadas por culturas específicas). Para melhor exemplificar, leia-se o seguinte:

se politicamente Portugal é hoje uma nação separada do Brasil que é a sua projeção no Trópico americano, sob aspecto cultural os dois têm sido há mais de um século partes igualmente vivas da mesma realidade lusotropical, ainda em pleno desenvolvimento. Desenvolvimento na América e desenvolvimento na África; e sobrevivência no Oriente. De modo que estamos - ao que parece - diante de um processo de formação de um terceiro homem ou de uma terceira cultura - um homem simbioticamente lusotropical, uma cultura simbioticamente lusotropical - de que vem resultando uma realidade ainda inacabada; e que se tem formado por ter o Português ido ao extremo, em época decisiva para o seu desenvolvimento extra-europeu, de, como nenhum outro europeu até hoje, ter renunciado à sua pureza, quer étnica, quer cultural, a favor de formas híbridas de homem e de cultura, das quais vêm participando raças, ambientes e culturas tropicais transeuropeizadas pela presença, entre elas, do Português (FREYRE, 1961: 88). ${ }^{16}$

Desde 1926, por ocasião da luta na cidade de Recife (PE) em defesa do Regionalismo como movimento cultural, Gilberto Freyre insistia na tese de que com base no espaço regional é que se deveria pensar a organização societária brasileira. Mais importante do que pensar o Brasil a partir dos Estados da União, seria pensá-lo regionalmente. Com isso seria possível definir de outro modo a integração nacional. A Nação se definiria nas suas particularidades regionais e esse complexo inter-regional seria inserido transregionalmente num complexo maior - o Trópico. Para consumar a efetividade de tal assertiva, sugere o autor uma sociologia situacional, termo teórico-metodológico que forneceria o instrumento heurístico de estudo empírico do homem-tropical e sua inserção cultural no lugar-região em que define suas práticas de cultura.

Nessas especificidades se encontrariam os aspectos múltiplos da unicidade civilizatória. Pela característica estrutural 
da simbiose inter-racial, essas diversidades regionais nunca iriam sugerir qualquer atitude separatista, ao contrário, a marca estrutural que Freyre acreditava caracterizar todo o processo histórico lusotropical estaria dada pelo equilíbrio de antagonismos. O Estado Nacional, para se consumar efetivamente como centro organizatório, deveria estimular a formação de suas instituições com essa característica inter-racial e inter-regional e as Forças Armadas seriam a marca institucional exemplar nesse papel de manutenção do equilíbrio de antagonismos ${ }^{17}$.

O lusotropicalismo - como ciência específica de uma nova civilização em processo de constituição nos trópicos, bem como centrado na concatenação lógica do que o autor conceitua relacionalmente como raças situadas em regiões-áreas que determinam uma região como área total (o trópico), historicamente em luta incessante pelo equilíbrio de antagonismos - já na década de 1950, apontava as possibilidades de caracterização de uma meta-raça e de uma terceira via à bipolaridade ${ }^{18}$.

O lusotropicalismo demarcava também, um novo conceito de tempo histórico: o tempo tríbio. O autor, segundo a mesma lógica centrada no equilíbrio de antagonismos, escreve que o homem lusotropical, na sua experiência histórica, desenvolvera uma

crescente consciência de conciliar, no tempo [o] tempo vivido, tempo presentemente vivido e tempo a ser vivido. Três tempos, que, em sua totalidade ou em sua fusão dinâmica, constituem, (...) um tempo tríbio, não lhe repugnando nem a experiência do passado nem a preocupação com o futuro, pela só adesão a uma vivência actual que fosse um viver separado dos dois outros. (FREYRE, 1972: 324).

Com essa afirmação, a lógica social do tempo nos trópicos teria de ser caracterizada como diferenciada daquela dos países não tropicais. Afirma que no espaço lusotropical, o tempo foi durante 
séculos adoçado pelo lazer, pelo ócio; [nos trópicos] há um conflito entre o gosto pelo ócio e a paixão pelo negócio, o tempo do ócio e o tempo do negócio, que mesmo sendo aparentemente contraditórios, para os habitantes dos trópicos, para os próprios negócios o tempo se realiza mais em tempo de ócio do que de negócio. (FREYRE, 1975: 44).

Apesar dessa característica, o autor sustentava que as empresas, nos trópicos, não se viram impedidas de desenvolvimento, quer material, quer moral e intelectual; embora tais empresas fossem realizadas em condições físicas de clima consideradas incompatíveis pelos europeus. A incompatibilidade estaria apenas no ritmo de realização - o ritmo ecológico dos trópicos, mais lento - do trabalho e da produção, portanto, o ritmo da atividade capitalista aí seria diferenciado daquele dos países de clima temperado ${ }^{19}$.

Em suma, o lusotropicalismo, nessa rápida caracterização, tinha todos os elementos para ser apropriado pelo corpo de gestores do Estado português. Esses gestores, numa gigantesca engenharia de propaganda política, incorporaram 0 lusotropicalismo como termo de defesa da unidade do Império. E com tais práticas, perceberam-se, na esfera do discurso, estranhas transfigurações lampedusianas junto a personagens emblemáticos do regime. O caso de $\operatorname{Salazar}^{20}$ é o mais expressivo dessa apropriação das teses lusotropicalistas de Freyre pelo corpo ideológico-administrativo do Estado fascista português. Com tais transfigurações, consumava-se a poderosa estratégia de manutenção do regime sobre o seu espaço colonial e sobre os seus opositores internacionais.

\section{III}

Apresento, para melhor exemplificar, ainda que rapidamente, o caso da apropriação do lusotropicalismo por Salazar. Gil (1995) ${ }^{21}$, num extraordinário estudo de análise dos discursos de Salazar, afirma que a natureza estrutural das 
intervenções públicas do ditador, principalmente nos discursos declamados aos rádio-ouvintes, seguia a mesma lógica das "narrativas de salvação". As intervenções obedeciam quase sempre à seguinte lógica de exposição: num primeiro momento era exposta "a situação de desordem, de mentira, de anarquia, de humilhação" porque passava Portugal ou o povo português; em seguida apresentava "o sacrifício para a cura" e, num terceiro momento, o da "regeneração", havia a renovação do corpo nacional graças à ação do Estado Novo e do seu chefe Salazar -, pois o "futuro imediato [assinalava] a renovação; o futuro distante [representava] o momento da grandeza mítica da nação, uma nova idade do ouro" (GIL, 1995: 23-24). Diante dessa lógica argumentativa, fica fácil perceber como a estrutura interna que define conceitualmente o lusotropicalismo se acomodaria a esse tipo de estrutura discursiva.

Salazar afirmava em 1959 que os territórios de Angola e Moçambique eram "independentes com a independência da Nação", afinal,

um nativo de Angola, embora com as limitações de sua incultura, sabe que é português e afirma-o tão conscientemente como um letrado de Goa, saído de uma universidade européia. Quer dizer, em vez de uma política de domínio ou educação, ainda que paternal, mas toda conduzida no sentido de constituir uma sociedade independente e estranha, o português, por exigência do seu modo de ser, previsão política ou desígnio da Providência, experimentou juntar-se, senão fundir-se, com os povos descobertos, e formar com eles elementos integrantes da mesma unidade pátria. Assim nasceu uma Nação sem dúvida estranha, complexa e dispersa pelas sete partidas do mundo; mas quando olhos que sabem ver perscrutam todas essas frações de nação, encontram nas consciências, nas instituições, nos hábitos de vida, no sentimento comum que ali é Portugal. (SALAZAR, 1959: 374, grifos meus).

Percebe-se a elipse retórica: a nação sem dúvida estranha. Tinha que ser assim - estranha - porque, historicamente, para Freyre - de quem Salazar tira tal afirmação - aquelas 
características só o Brasil as tinha, daí o termo possível ser exatamente esse: uma nação estranha. Outra ilação surge como indagação: que olhos é que souberam ver essa estranha nação dispersa pelas sete partidas do mundo, senão os olhos de Gilberto Freyre? A diferença no uso estaria no objeto. Salazar queria afirmar Portugal e Freyre afirmava o Brasil. Aqui está a diferença substancial entre as duas práticas discursivas dentro do lusotropicalismo percebido como um campo ideológico.

As justificativas da permanência do Império corroboravam, para Salazar, a unidade de defesa da civilização cristã.

Não nos temos cansado de dizer que a África é complemento natural da Europa, necessária à sua vida, à sua defesa, à sua subsistência. Sem a África, a Rússia desde já pode ditar ao Ocidente os termos em que lhe permite viver. (SALAZAR, 1959: 371-372). ${ }^{22}$

Ou seja, na lógica da Guerra Fria, Salazar defendia a manutenção do Império como fronteira civilizacional contrária às ameaças expansionistas da URSS. Sugere-se com tal assertiva que Portugal, na sua consciência política nacional, estaria novamente numa luta cristã contra os bárbaros. E dessa maneira, Portugal reencontraria o seu destino - o de ser a última fronteira de defesa da civilização cristã ocidental, que naquele momento caracterizava-se como a última fronteira de defesa, para a Europa, da ameaça da "barbárie" comunista. Mas esse reencontro com o destino era um reencontro sem futuro, seria apenas a reafirmação do passado de glórias camonianas ${ }^{23} . \mathrm{Na}$ verdade, a formulação retórica traía Salazar, porque era sempre em um passado mítico que se definia no presente o tempo de uma historicidade sem futuro. A elegia passadista, ao apresentar a esperança do futuro, só conseguia trazer à tona os fantasmas de um passado feudal, ou melhor, pré-capitalista.

Talvez assim se explique a insistência do Estado salazarista, dos seus principais intelectuais (Adriano Moreira foi o maior exemplo) e do próprio Gilberto Freyre, em caracterizar a colonização dos trópicos pelos portugueses como cristocêntrica. Nas palavras de Salazar: 
a nossa ação ultramarina antecedeu de alguns séculos a revolução industrial, foram desde logo diferentes os objetivos: a par do fomento do comércio, orientámo-nos sempre, no contato com as populações locais, pelo ideal de igualdade do homem perante Deus e a lei, qualquer que fosse a sua raça, e pelo estabelecimento de laços de solidariedade humana que transcendiam o plano dos interesses materiais. (...) É aí que reside a diferença entre a ação ultramarina de Portugal e a dos outros países europeus que tiveram ou ainda têm colônias. (SALAZAR, 1989: 245-246).

Junto a esses elementos, convém ainda destacar o antiamericanismo de Salazar: "quero este país (Portugal) pobre, se necessário for, mas independente: e não o quero colonizado pelo capital americano". (apud MAXWELL, 1999: 22). Freyre era da mesma opinião, pelo menos até o final da década de 1950 . Nada o irritava mais do que a presença no Brasil de capitais e valores estrangeiros, principalmente aqueles oriundos do imperialismo norte-americano. Contudo, ele muda radicalmente de opinião no começo da década de 1960, quando passa a apoiar explicitamente o projeto do presidente John Kennedy denominado Aliança para o Progresso.

$\mathrm{E}$ ainda, além de apresentar-se como uma alternativa civilizacional à bipolaridade, o projeto salazarista buscava efetivamente a realização do que os gestores do Estado português procuravam definir como espaço econômico português, "um espaço fechado e protegido" (TELO, 1994: 268269). Isso significava um mercado capitalista de uso quase que exclusivo, onde Portugal pudesse renascer como nação e reencontrar as "grandezas" expropriadoras do seu passado.

Com o discurso de Salazar, referendava-se em definitivo a presença do ideário freyriano na cultura política do Estado Salazarista. Os exemplos são múltiplos. Já destaquei o esforço de Adriano Moreira, a interpelação de Sarmento Rodrigues e a do próprio Salazar. E para finalizar essa demonstração de procedimentos institucionais junto ao programa lusotropicalista, apresento a seguir como a teoria freyriana foi também utilizada 
como arma do regime num espaço institucional internacional, o mais significativo e o mais problemático - a ONU.

Os trabalhos diplomáticos de Portugal naquele fórum ficaram a cargo do ministro Franco Nogueira. Este suportaria uma verdadeira guerra diante da oposição internacional ao colonialismo português. Das tribunas, ao rebater os críticos de Portugal, entre outros argumentos, Franco Nogueira afirmava:

A Nação portuguesa por se encontrar dispersa em vários continentes, não está cometendo um crime (...). Vimos que a geografia, em si própria, não implica qualquer idéia de colonialismo (...) a Nação portuguesa é como é há 500 anos. (...) A Nação é uma só, e até onde chega a Nação terá de chegar o Estado. Esta é precisamente a razão por que a nossa constituição - de um estado unitário - não permite qualquer discriminação entre vários territórios. (NOGUEIRA, 1962: 219).

Veja-se o argumento: "a Nação portuguesa é como é há 500 anos". Mais uma vez a afirmação de um presente como passado, a afirmação de um destino sem futuro. E num outro momento, rebatendo alguns estudos que comissões da ONU apresentavam contra o colonialismo de Portugal, o corpo diplomático português na pessoa de Franco Nogueira - assim argumentou:

Esperávamos que as delegações, seriamente interessadas, fariam estudos sérios e independentes, e para o efeito poderiam ter consultado uma vasta bibliografia. Mas nem uma alusão foi feita a obras fundamentais como do Professor Trend, da Universidade de Londres; (...) do Professor Gilberto Freyre, do Brasil; (...) ou do Professor Toynbee, da Inglaterra. (NOGUEIRA, 1962: 226).

Novamente fez-se uso da autoridade intelectual de Gilberto Freyre, internacionalizado, como termo justificatório dos procedimentos colonialistas do Estado português. No entanto, apesar de todos os aspectos apresentados que corroboram um Freyre salazarista, é necessário fazer referência a um aspecto que possa estar "descolando" Freyre do campo ideológico 
salazarista, ou pelo menos lhe oferecendo certo caráter de autonomia.

$\mathrm{Na}$ lógica do que foi exposto até aqui, percebe-se que Portugal afirmava sua "grandeza" civilizacional na reafirmação do passado. O espaço colonial do Império, principalmente nos territórios da África, seria então a afirmação do tempo presente ${ }^{24}$, isto é, Portugal consumava o tempo passado na lógica do tempo presente africano. E o Brasil? Na lógica do exposto, o Brasil que já fora colônia, já se realizara, em determinado momento, como o tempo presente de Portugal. Mas naquela circunstância, nas décadas de 1950 e 1960, como nação independente que era, o Brasil afirmava-se como o tempo futuro para aquele tempo presente, isto é, como a síntese dos Tempos dos Trópicos. Em outras palavras, o Brasil seria o tempo futuro da "civilização lusotropical" em formação.

Desse modo, a aproximação de Freyre com o Portugal de Salazar não acontecia para afirmar a liderança de Portugal dentro do mundo lusotropical, mas para afirmar a liderança do Brasil. Portugal seria, para Freyre, o tempo passado já afirmado, que só podia se realizar como nação no tempo presente de uma África ainda em formação; já o Brasil, tendo suplantado aquele tempo passado e aquele tempo presente, seria a afirmação, já naquele momento, do tempo futuro dos Trópicos. Dessa maneira, o Brasil seria a síntese do tempo tríbio. Possivelmente essa seja uma hipótese para "descolar" Gilberto Freyre do campo ideológico salazarista, de não o perceber apenas como mais um dos cães de guarda de Salazar, e talvez assim, apresentá-lo como um intelectual que dentro de um determinado campo ideológico - o fascismo salazarista - lutava para fazer do lusotropicalismo (que poderia ser definido como um subcampo ideológico no espectro salazarista) uma afirmação teórico-científica hegemônica nas ciências sociais contemporâneas. Ainda que tal afirmação, pelos exemplos citados, possa ser ambígua, essa hipótese também pode ser aferida pelos fatos descritos. 


\section{IV}

O Brasil, como "potência média", como potência com autonomia no concerto diplomático de hostilidades da bipolaridade geopolítica, e mais, como potência líder de uma região, era um país que demarcava uma alternativa civilizacional frente àquelas do capitalismo norte-americano e/ou do comunismo soviético. Esses eram os reais propósitos que o lusotropicalismo visava enquanto modelo teórico e marco ideológico-doutrinal.

Em julho de 1958, na Faculdade de Direito da Universidade de Minas Gerais, Gilberto Freyre apresentou uma conferência intitulada "Uma Política Transnacional de Cultura para o Brasil de hoje"25. Transcrevo, a seguir, algumas passagens dessa conferência, corroborando assim a hipótese acima referida, a de que Gilberto Freyre tinha suas reflexões direcionadas a um projeto brasileiro de hegemonia geopolítica e não meramente de transformar suas reflexões em apologia do regime salazarista. Naquela conferência, o autor afirmou:

Ao Brasil de hoje abrem-se oportunidades de povo condutor de povos tropicais menos adiantados, acompanhadas de responsabilidades que se não forem assumidas pelos indianos ou pelos árabes unificados, pela Venezuela ou pelo México, ficando os brasileiros reduzidos a uma situação politicamente inerme entre esses povos quando, sob tantos outros aspectos, sua civilização simbioticamente lusotropical ou hispanotropical talvez seja a mais completamente integrada, a mais vivamente criadora e também a mais dinâmica das modernas civilizações que se desenvolvem nos trópicos. (FREYRE, 1960a: 52).

Com esse diagnóstico de realidade, o autor constatava uma paralisia decisória na ação do Estado brasileiro para a consecução dos fins propostos acima. De todas as experiências históricas de sociedade nos trópicos, a experiência brasileira era, naquela ocasião, "a mais arrojada: a vanguarda de todas elas". Dessa maneira, impunha-se ao Brasil a missão histórica de 
liderar a civilização lusotropical, "civilização em desenvolvimento" e ainda "não estabilizada". Para tanto, o autor propunha ao Brasil o papel de potência média e líder, comandando uma "federação de países de língua portuguesa" (FREYRE, 1960a: 59-60).

Em suma, ainda que não seja explícito, naquela data, Gilberto Freyre, com suas assertivas culturalistas, justificava como favorável a ideia de realização do espaço econômico português, que os gestores lusitanos só viriam a propor efetivamente a partir de 1961. Um projeto idealizado desde o início da década de 1950, principalmente por causa da pressão revolucionária de grupos africanos autonomistas e anticolonialistas (em janeiro de 1961, aconteceram em Angola os primeiros atos "terroristas" ao regime colonialista comandados por grupos políticos que, anos depois, constituíram o Movimento Popular para a Libertação de Angola - MPLA). E isso determinaria também a posição de Freyre nos debates sobre os destinos da Revolução capitalista brasileira.

Gilberto Freyre sempre foi um intelectual vaidoso. Buscava em cada auditório o espelho do seu thymos. O aplauso fascinavao. Ninguém escreveu melhor sobre ele do que ele mesmo. Mas a sua vaidade sempre teve uma mordaça de ressentimento. A parcela mais significativa da cultura acadêmica, nas áreas de sociologia, antropologia e história, do eixo Rio - São Paulo, não reconhecia a grandeza intelectual que outros destacavam em Freyre, por exemplo, na França, em Portugal e nos EUA. Gilberto Freyre nunca foi aceito pelo mundo acadêmico do eixo Rio - São Paulo. Sempre foi alvo de pesadas críticas. E mais, Freyre não permitia - em termos formais de pesquisa acadêmica - uma cultura de pesquisas e investigações científicas que tivessem sua obra personalíssima como matriz teórica e epistemológica. Lutou exasperadamente para modificar essa situação com a criação do seu "feudo regional" particular, o Instituto Joaquim Nabuco de Pesquisas Sociais (IJNPS), que viria a ser depois a Fundação Joaquim Nabuco (FUNDAJ). Lá tentou organizar a ciência a serviço da modernização do Nordeste e do país, mas para isso teve que conviver com 
"laudação" enxovalhante de alguns intelectuais provincianos que em pouco ou nada problematizavam a sua obra.

Gilberto Freyre precisou de Portugal para justificar as factibilidades do seu modelo teórico. Lá encontrou admiradores efetivos de sua obra, inclusive de intelectuais de esquerda caso do historiador socialista antissalazarista António Sérgio bem como teve a vaidade lustrada ao máximo, com a viagem de sete meses pelo Império (de agosto de 1951 até fevereiro de 1952) e as recepções pelas colônias, etc. Ainda que seus propósitos não apontassem o mesmo sentido político para Portugal no mundo como os portugueses o faziam, deixou-se instrumentalizar pela retórica do campo ideológico salazarista. Mas foi uma retórica de fundação, de confecção de realidades materiais, de práticas concretas e não de uma pretensa comunidade imaginária. Não existem comunidades imaginárias. Toda comunidade é afirmação concreta de práticas históricas em processo, em luta ideológica, logo, é realidade material de classe. Só assim é possível entender o lusotropicalismo como realidade concreta teórico-prática.

O Império português permaneceu com suas fronteiras praticamente intactas até 1975. É um enigma historiográfico o entendimento dos porquês de sua longa duração, ainda mais se essa permanência se justificou naquilo que Perry Anderson definiu como uma "lânguida profusão verbal" que tornava a sua realidade pura maleabilidade (ANDERSON, 1966: 84). Evidentemente, outras contradições poderiam ter sido aqui apresentadas, principalmente aquelas de ordem econômica; delimitei-me, contudo, na indicação do papel histórico da teoria freyriana como termo fundacionista dessa prática concreta de manutenção do Império - em como o lusotropicalismo deu sentido histórico-estrutural à manutenção ideológica de um Império anacrônico, instrumentalizando para isso a retórica fundacional de alguns dos "cães de guarda" desse Império.

A solução para o enigma da permanência do Império está na análise das demandas das forças socioeconômicas agregadas ao Estado salazarista. Para isso, sugiro o estudo sobre o papel econômico e político das Companhias Majestáticas, que 
controlavam a atividade produtiva de maneira privada dentro do espaço colonial, as quais se tornariam um Estado dentro do Estado. Empresas que, sozinhas, tinham sob seu controle territórios maiores que o de Portugal, como a DIAMANG (Diamantes de Angola); empresas que tinham, além disso, a total anuência do Estado português para poder impor o sistema de gestão e repressão aos trabalhadores sob seus únicos e exclusivos critérios, práticas capitalistas de um fascismo privado, que levaram, inclusive, ao protesto de Gilberto Freyre ${ }^{26}$. Nesse estudo (que sugiro como hipótese investigativa), revelar-seia como a administração de muitas dessas empresas esteve a cargo de alguns dos membros da administração pública salazarista, caso exemplar é o do ministro Armindo Monteiro ${ }^{27}$. E justificar-se-ia uma tese fundamental para explicar a manutenção do Império: a eficácia do regime graças à ação dos gestores como classe, na organização do Estado salazarista ${ }^{28}$. No pós-guerra, foram os gestores que organizaram as formas de reprodutibilidade capitalista portuguesa, tanto em Portugal, como nas colônias do ultramar.

O processo de realização, tão desejada, de uma federação de nações de língua portuguesa foi descrito como um anseio de classe pela retórica de um dos artífices da transição nos acontecimentos da revolução de abril de 1974 - o General Antônio de Spínola. Por meio de seu livro, publicado em fevereiro de 1974 com o título Portugal e o Futuro, haveria de manifestar como estrutural o aporte explicativo do lusotropicalismo ao projeto neocolonialista português ${ }^{29}$.

O lusotropicalismo como referência ideológica das práticas institucionais de alguns dos principais gestores do salazarismo haveria de permanecer por algum tempo junto à conjuntura que derrotara politicamente o salazarismo, conjuntura que consolidou a Revolução dos Cravos. Basta perceber nessa conjuntura a presença política do General Spínola, que se tornou Presidente da República, e constatar ainda a presença, nos primeiros momentos, do novo regime, de Sarmento Rodrigues pelo que se depreende da correspondência mantida com Gilberto Freyre ${ }^{30}$, o qual continuou sendo, durante algum tempo, 
um nome lembrado na configuração dos destinos políticos que o novo regime pós-salazarista traçava.

\section{REFERÊNCIAS BIBLIOGRÁFICAS}

ALEXANDRE, Valentin. Velho Brasil / novas Áfricas: Portugal e o Império (1808 - 1975). Porto: Afrontamento, 2000.

ANDERSON, Perry. Portugal e o fim do ultracolonialismo. Rio de Janeiro: Civilização Brasileira, 1966.

BARRADAS, Ana. Ministros da noite: livro negro da expansão portuguesa. Lisboa: Antígona, 1995.

BASTOS, Élide Rugái. Gilberto Freyre e a questão nacional. In: MORAES, Reginaldo et al. Inteligência brasileira. São Paulo: Brasiliense, 1986, p. 43-76.

BERNARDO, João. Marx crítico de Marx. Porto: Afrontamento, 1975. v. 3. BERNARDO, João. Economia dos conflitos sociais. São Paulo: Cortez, 1991. BOBBIO, Norberto. Os intelectuais e o poder. São Paulo: Edunesp, 1995. CAETANO, Marcello. O conselho ultramarino: esboço de sua história. Lisboa: Agência Geral do Ultramar, 1967.

CASTELO, Cláudia. O modo português de estar no mundo: o lusotropicalismo e a ideologia colonial portuguesa (1933 - 1961). Porto: Afrontamento, 1998.

CASTRO, Armando. O sistema colonial português em África (meados do século XX). Lisboa: Editorial Caminho, 1980.

FREYRE, Gilberto. Uma política transnacional de cultura para o Brasil de hoje. Revista Brasileira de Estudos Políticos; Belo Horizonte, MG: Faculdade de Direito da Universidade de Minas Gerais, 1960a.

FREYRE, Gilberto. Integração portuguesa nos trópicos. In: FREYRE, G. Uma política transnacional de cultura para o Brasil de hoje. Revista Brasileira de Estudos Políticos. Belo Horizonte, MG: Faculdade de Direito da Universidade de Minas Gerais, 1960b, pp. 65-117.

FREYRE, Gilberto. O luso e o trópico. Lisboa: Comissão Executiva das Comemorações do V Centenário da Morte do Infante D. Henrique, 1961. FREYRE, Gilberto. 6 conferências em busca de um leitor. Rio de Janeiro: Livraria José Olympio, 1965.

FREYRE, Gilberto. Novo mundo nos trópicos. Lisboa: Edição Livros do Brasil Lisboa, 1972.

FREYRE, Gilberto. Ordem e Progresso (3a. edição) (2 vols.). Rio de Janeiro: José Olympio Editora / INL, 1974. 
FREYRE, Gilberto. O brasileiro entre os outros hispanos: afinidades, contrastes e possíveis futuros nas suas inter-relações. Rio de Janeiro: Livraria José Olympio Editora; Brasília: INL - MEC, 1975.

FREYRE, Gilberto. Rurbanização: Que é? Recife: Editora Massangana / Fundação Joaquim Nabuco, 1982.

GIL, José. Salazar: a retórica da invisibilidade. Lisboa: Relógio D’Água Editores, 1995.

LEONARD, Yves. Salazarisme et Lusotropicalisme, histoire d'une appropriation. In: Lusotopie 1997. Paris: Editions Karthala / CNRS, 1997, pp. 211-226.

LEONARD, Yves. Salazarismo e fascismo. Sintra: Editorial Inquérito, 1998.

MAIO, Marcos Chor. Tempo controverso: Gilberto Freyre e o projeto Unesco. In: Revista Tempo Social, São Paulo, maio.1999, n. 11 (01), pp. 111-136.

MAXWELL, Kenneth. A construção da democracia em Portugal. Lisboa: Editorial Presença, 1999.

MENDES, Nuno Canas. A projecção do pensamento de Adriano Moreira no instituto superior de ciências sociais e políticas. In: BARATA, Óscar Soares et al. Estudos em homenagem ao professor Adriano Moreira. Lisboa: Instituto Superior de Ciências Sociais e Políticas / Universidade Técnica de Lisboa, 1995, p. 773-782. v. 1 e 2.

MOREIRA, Adriano. Em lembrança de Gilberto Freyre. In: Revista Ciência \& Trópico, Recife, jul.1987 e dez.1987, V. 15 (2), p. 187-192.

NETO, Maria da Conceição. Ideologias da colonização de Angola. In Lusotopie 1997. Paris: Editions Karthala / CNRS, 1997.

NOGUEIRA, Franco. As nações unidas e Portugal. Lisboa: Ática, 1962. PINTO, João Alberto da Costa. Os impasses da intelligentsia diante da revolução capitalista no Brasil (1930 - 1964): historiografia e política em Gilberto Freyre, Caio Prado Júnior e Nelson Werneck Sodré. Niterói, 2005. 296 p. Tese (Doutorado em História Contemporânea) PPGH, UFF. ROSAS, Fernando; BARROS, Júlia Leitão de; OLIVEIRA, Pedro de. Armindo Monteiro e Oliveira Salazar: correspondência política 1926 1955. Lisboa: Editorial Estampa, 1996.

SALAZAR, António de Oliveira. Discursos e notas políticas. Coimbra: Coimbra Editora Ltda., 1959. v. 5

SALAZAR, António de Oliveira. Pensamento e doutrina política: textos antológicos. Lisboa: VERBO, 1989.

SANTOS, Luiz Antonio de Castro. O pensamento social no Brasil. Campinas, SP: Edicamp, 2003. 
SARAIVA, José Flávio Sombra (org.). Relações internacionais contemporâneas: da construção do mundo liberal à globalização (de 1815 a nossos dias). Brasília: Paralelo 15, 1997.

SOUZA, Jessé. A modernização seletiva: uma reinterpretação do dilema brasileiro. Brasília, DF: Editora da UNB, 2000.

SPINOLA, Antônio de. Portugal e o futuro. Rio de Janeiro: Editora Nova Fronteira, 1974.

TELO, António José. Economia e império no Portugal contemporâneo. Lisboa: Edições Cosmos, 1994.

VENÂNCIO, José Carlos. Colonialismo, antropologia e lusofonias: repensando a presença portuguesa nos trópicos. Lisboa: VEGA, 1996.

PINTO, João Alberto da Costa. Gilberto Freyre e a intelligentsia salazarista em defesa do Império Colonial Português (1951 - 1974). História, v.28, n.1, p.445-482, 2009.

\begin{abstract}
In this paper, I intend to analyze Gilberto Freyre's trajectory within the Salazarist Intelligentsia from 1951 onwards, a time of Salazar's statutory redefinitions of colonial administration. I also reflect upon how Freyre's theoretical model, Lusotropicalism, was appropriated as a key element for the internationalization of the ideological-institutional justification in defense of the maintenance of the Portuguese Colonial Empire.
\end{abstract}

Keywords: Gilberto Freyre; Lusotropicalism; Salazarism.

\title{
NOTAS
}

${ }^{1}$ Ver, por exemplo, os trabalhos de Santos (2003), principalmente, os capítulos 01 e 03; e Souza (2000: 210), que ao se referir ao conjunto da obra freyriana afirma: "sua obra de juventude é marcada pelo tom aberto, propositivo, hipotético, o que [leva] alguns comentadores a interpretá-lo pelo paradigma da ambigüidade e da contradição constitutivas. Foi precisamente esse aspecto aberto, inquisitivo, de sua obra de juventude, que foi substituído na maturidade por um espírito de sistema fechado, uma compilação de certezas e de sugestões de intervenção prática e política". No entanto, o intérprete escolhe o livro 
Sobrados e Mocambos como a melhor obra de Freyre, apenas pelo critério das "brilhantes intuições" (SOUZA, 2000: 211), desqualificando sumariamente o conjunto da produção freyriana das décadas de 1950 e 1960, numa afirmação que me parece insustentável: "O certo é que a obra madura de Freyre é uma espécie de caricatura de sua obra de juventude" (SOUZA, 2000: 211).

${ }^{2}$ Desenvolvi na minha tese de doutoramento uma análise global sobre o conjunto da trajetória teórico-institucional de Gilberto Freyre. Ver Pinto (2005).

${ }^{3}$ Liberalizantes porque se determinou como prática comumente aceita o direito à autodeterminação dos povos, logo, os espaços coloniais, como resíduos de uma fase de expansão territorial imperialista, tornavam-se crescentemente anacrônicos diante da nova situação do mundo no pósguerra (1945). Sobre a questão da autodeterminação dos povos no pósguerra, a historiadora Cláudia Castelo afirma: "a ONU passa a considerar o princípio da autodeterminação como um direito humano fundamental, e atribui às potências coloniais a obrigação de prepararem os territórios sob sua administração para a independência" (CASTELO, 1998: 49).

${ }^{4}$ Sobre o Acto Colonial, consultar Alexandre (2000: 188) que afirma: "O Acto Colonial tinha antes de mais um objetivo político preciso: tratavase de reafirmar de forma solene a soberania portuguesa no Ultramar, em documento com valor constitucional, dando-lhe um caráter permanente e irrevogável, numa fase em que se agudizavam as tensões com a Sociedade das Nações sobre a questão do trabalho indígena e em que se falava da 'internacionalização' dos territórios coloniais. Daí a expressão enfática do seu artigo $2^{\circ}$.: 'É da essência orgânica da Nação Portuguesa desempenhar a função histórica de possuir e colonizar domínios ultramarinos e de civilizar as populações indígenas que nelas se compreendam (...)'. Assim se retomava o tema da defesa do império, tão caro às elites políticas portuguesas". E para a compreensão das razões políticas que levaram Salazar a elaborar esse documento em 1930 e a republicá-lo em 1933, consultar também o estudo de Leonard (1998), especialmente a página 47.

${ }^{5}$ É conhecida a expressão "cães de guarda". Foi criada por Paul Nizan em 1932, num pequeno ensaio - Les Chiens de Garde (apud BOBBIO, 1995). Nizan denunciava os intelectuais que se comprometiam com o poder do Estado e traíam assim uma possível "verdade" histórica, em nome da vontade do poder. É com esse sentido que uso a expressão para caracterizar a intelligentsia salazarista. 
${ }^{6}$ A proposta de se substituir o termo colônias por províncias ultramarinas era vista por Armindo Monteiro como sinal de fraqueza, por isso, afirmava: "Angola, Moçambique e até a Guiné têm províncias, não são províncias" (apud CASTELO, 1998: 55). Em seu texto Castelo (1998: 55) ainda complementa: "O discurso oficial procura adaptar-se à nova situação internacional. Prefere abrir mão das palavras para não ser forçado a abrir mão das coisas, apesar das dificuldades e das pressões externas" (grifos do autor). A autora acrescenta que Armindo Monteiro, que tinha sido Ministro das Colônias entre 1931 e 1935, concebia a ideologia colonial como algo atemporal, e como entusiasta do Acto Colonial acreditava na irremediável inferioridade da raça negra. Armindo Monteiro representava ideologicamente uma matriz racista e determinista que foi hegemônica dentro do Estado na década de 1930. Como ministro das Colônias, num discurso proferido em primeiro de julho de 1933, teve a oportunidade de assim se referir sobre as sociedades africanas: "Nenhum sopro de ambição as anima. Diante do milagre da penetração da selva pelo homem branco permanecem insensíveis. A sua nudez externa é o espelho da sua nudez moral. Estará ainda o europeu a tempo de salvar essas sociedades, que parece só por ela esperam? Julgo que a selecção natural irá operando os seus efeitos e que, dentro de poucas dezenas de anos, da face da terra terão desaparecido as raças negras que não puderam escalar as ásperas sendas da civilização" (apud BARRADAS, 1995: 72-73)

${ }^{7}$ Sobre o fim do Acto Colonial, escreveu Marcello Caetano: "As palavras têm as suas épocas... Colónia fora a expressão da política autonomista que o regime republicano trouxe no seu programa. O movimento nacionalista que faz o seu caminho após 1926 toma o termo Império como lema. Mas após a segunda grande guerra, com a crescente ofensiva anti-colonialista e a oposição aos nacionalismos, tornava-se conveniente abandonar uma terminologia que se prestasse a equívocos. Foi-se então ao vocabulário tradicional buscar velhas designações de ultramar e província ultramarina para as utilizar outra vez substituindo sistemática e inexoravelmente todas as referências e designações proscritas. Tal foi o caminho traçado pela reforma constitucional de 1951 que, integrando a matéria do Acto Colonial no texto da Constituição ...". (CAETANO, 1967: 103).

${ }^{8}$ Nota-se tal aspecto, por exemplo, em alguns dos seus textos publicados em Portugal, na década de 1950. Deles destaco, principalmente, o ensaio "Integração Portuguesa nos Trópicos", que é de 1958 e foi publicado pelo CESP (em conjunto com o Ministério do Ultramar) dirigido então por Adriano Moreira. Foi publicado em português e em inglês e distribuído pelo corpo diplomático português a todas as "embaixadas, consulados e 
delegações de Portugal espalhados pelo mundo" (CASTELO, 1998: 99). Juntamente com os exemplares do texto de Freyre era remetida a seguinte circular do Ministério do Ultramar: "Tenho a honra de enviar a V. Exa., em separado, [X] exemplares duma publicação do Ministério do Ultramar sobre o tema Integração Portuguesa nos Trópicos. Como essa Missão verificará trata-se dum valioso estudo, em língua portuguesa e inglesa, do iminente professor, acadêmico e historiador brasileiro Gilberto Freyre, que põe em relevo alguns aspectos mais notáveis da expansão portuguesa nas suas relações com povos e raças diferentes. Parece vantajosa a utilização de referido estudo e por isso conviria que essa Missão não deixasse de o remeter às entidades que possam interessar" (CASTELO, 1998: 100, grifos meus).

${ }^{9}$ Sarmento Rodrigues não fez uma carreira acadêmica. A apesar de ter publicado vários livros e inúmeros artigos, foi como gestor que se tornou um dos personagens mais representativos do regime após as reformas de 1951. Foi Comodoro da Marinha portuguesa, governadorgeral da Guiné (1945 - 1949), Ministro do Ultramar (1950 - 1955) e governador-geral de Moçambique (1961 - 1964). Leonard (1997) afirma que Sarmento Rodrigues encarnava uma corrente liberal dentro do regime salazarista. Na década de 1960, chegou a propor uma espécie de autonomização das colônias da África auxiliada com a transferência da administração portuguesa, ou seja, para ele o futuro de Portugal estaria numa África independente. Sarmento Rodrigues defendia também a tese do espaço econômico português. Já Adriano Moreira saiu dos quadros acadêmicos para os quadros do Estado e tornou-se, com sua vasta obra, um dos maiores intelectuais do regime no momento das reformas pós-1951. Desenvolveu um modelo teórico - o Institucionalismo. "Com origens em pensadores franceses (Hauriou e Renard), esta teoria política considera os homens e as idéias dois fenômenos capitais que asseguram a perpetuação de concepções e modelos. Os homens são criaturas únicas e mortais, conseqüentemente fenômenos de caráter transitório: as idéias são intemporais e podem concretizar-se (...). Esta objetivação pode tomar a forma peculiar, a que se deu nome de Instituição e que: 'corresponde a uma idéia de obra ou empresa que se realiza e dura no meio social, interiorizando um quadro de recursos humanos e materiais ao seu serviço que excede a temporalidade das gerações e tende para a personalização jurídica'. A teoria em análise distingue-se das matrizes liberal e marxista por admitir que as instituições devem colaborar com o Estado no exercício do poder. Tal colaboração implica autonomia e não separação ou submissão, como acontece com as outras duas matrizes".(MENDES, 
1995: 773-782). O modelo teórico-político de Adriano Moreira, pela caracterização acima, demarcava-se em evidentes feições corporativotecnocráticas. Foi com esses dois intelectuais que Freyre estabeleceu os laços políticos e intelectuais mais profícuos com o regime salazarista.

${ }^{10}$ Uma descrição detalhada da organização do convite de Sarmento Rodrigues a Gilberto Freyre para a viagem científica ao Império português está em Castelo (1998: 90), na nota de número 109.

11 Escreveu Adriano MOREIRA: "Inteiro estava Gilberto nos Congressos das Comunidades de Cultura Portuguesa, que organizei em Moçambique. (...) No ato final do II Congresso, que teve lugar na Ilha de Moçambique em 1966, estavam representados vivos todos os valores que recolheu na sua obra prodigiosa: na velha fortaleza, portugueses, descendentes de portugueses e filiados na cultura portuguesa; bispos de todo o espaço da língua portuguesa; representantes de todas as outras igrejas e cultos; e em dois mastros, ao cair da noite sobre o Índico, pela primeira e talvez última ocasião, subiram as bandeiras de Portugal e do Brasil, com os hinos nacionais a proclamarem a convergência, e a convidarem os que não tinham ainda tais símbolos a olharem na mesma direção, em busca do ponto ômega que acreditamos poder ser atingido" (MOREIRA, 1987: 187-192).

${ }^{12}$ Gilberto FREYRE desenvolveu sua tese sobre o lusotropicalismo em inúmeras obras, das quais destaco: Interpretação do Brasil (1945), Aventura e Rotina (1953), Integração Portuguesa nos Trópicos (1958), Novo Mundo nos Trópicos (1959), e O Luso e o Trópico (1961). Em Casa Grande e Senzala (1933) já são definidos os fundamentos epistemológicos do lusotropicalismo. Destaco, neste artigo, o trabalho de 1958, por seu caráter de obra encomendada pelo regime. O livro de 1961 também foi encomendado. Esse livro apareceu em Portugal "em fevereiro de 1961, no exato mês em que eclodiu em Luanda - Angola a revolta que atestou perante o mundo o contrário da harmonia racial e da 'cordialidade' portuguesa" (NETO, 1997: 331). Relevo o grau de importância do texto de 1958 por ter sido uma referência de estruturação ideológica fundamental para as pretensões ideológicas do regime frente à questão colonial. O livro de 1961 acomodou-se a um evento comemorativo, também de importância fundamental para a reprodutibilidade do regime, mas, com um alcance estrutural de menor proporção. Em tempo, o ensaio da historiadora angolana Maria da Conceição Neto, acima citado, é um dos mais completos estudos de 
"desmontagem" das práticas "retóricas" portuguesas do processo colonialista do século XX.

${ }^{13}$ Utilizo a reedição desse texto que o autor publicou no Brasil.

14 E complementa o autor: "Se toda a filosofia da 'experiência' é caracterizada pelo que alguém já chamou de 'projeção', isto é, por uma conexão com o futuro que a induz a procurar ver o desconhecido com olhos de quem descobre e não de quem supõe estar tudo descoberto, esse característico não faltou aos começos do que hoje se possa denominar "lusotropicologia'" (FREYRE, 1960b: 70-71).

${ }^{15}$ Importa lembrar que até aquela data - 1958 - Freyre já tinha uma grande reputação internacional. Sua obra era traduzida e lida nos principais centros intelectuais do mundo. Como exemplo dessa projeção internacional, destaco a sua participação num fórum de debates organizado pela UNESCO - Tensions that cause wars, em 1946, em que Freyre, como único intelectual latino-americano, discutiu os possíveis rumos do mundo no pós-guerra. Naquela ocasião, teve como interlocutores vários intelectuais europeus e norte-americanos, entre eles, Georg Gurvitch e Max Horkheimer. Sobre essa reunião consultar Maio (1999). A pergunta que fica é: por que um autor de prestígio internacional como o que Freyre já obtinha, submeteu-se a um papel tão subserviente com o Estado salazarista? Pelo que já apresentei, é possível afirmar que a aceitação desse papel de "cão de guarda" deuse, não por apostar em Salazar, mas por encontrar nos portugueses uma recepção "científica" à sua obra, que nunca obtivera entre os intelectuais brasileiros, fato que o incomodava bastante. Para exemplificar esse argumento, cito uma passagem do seu texto Uma Política Transnacional de Cultura para o Brasil de Hoje (1960a: 51) quando, ao comentar a sua participação na $30^{a}$ Reunião do INCIDI, em 1957, na cidade de Lisboa, fez as seguintes observações: "Jornalistas de vários países interessaram-se em recolher do autor brasileiro (refere-se a si mesmo e à sua tese do lusotropicalismo) informações sobre o assunto que pudessem ser transmitidas ao grande público. Entre esses jornalistas, nenhum do Brasil ou ligado particularmente ao Brasil. (...) até hoje nenhuma publicação científica ou universitária brasileira mostrou-se de qualquer modo interessada no assunto (o lusotropicalismo). Nenhum editor brasileiro revelou até agora esse interesse de modo específico". Esse aspecto ajuda a entender, em parte, os esforços privatistas do autor, quando como Deputado Federal defendeu renhidamente a aprovação do que viria a ser seu feudo institucional - o IJNPS (Instituto Joaquim Nabuco de Pesquisas 
Sociais), projeto que conseguiu aprovar em 1949 (depois Fundação Joaquim Nabuco). Freyre lutava contra o seu isolamento no quadro da intelligentsia nacional. Nunca teve escrúpulo algum em defender os interesses particulares do seu modelo explicativo.

${ }^{16}$ Logo a seguir o autor complementava: "Outro não tem sido o sentido do desenvolvimento do Brasil (...) simbiose sócio-cultural ou étnicocultural e não simples 'associação' de puro 'caráter económico'. (...) Isto a despeito desse processo simbiótico ter sido perturbado por vezes, em áreas como Moçambique, pelo contágio das suas populações brancas com as populações intransigentemente européias das Rodésias e da África do Sul; e também em Angola, em subáreas de excepção, como a constituída pela poderosa Companhia de Diamantes, cujos líderes portugueses parecem ser adeptos da política belga ou inglesa de 'associação' com 'segregação' dentro de objetivos quase exclusivamente económicos de ocupação ou exploração dos Trópicos por Europeus" (FREYRE, 1961: 100).

${ }^{17}$ Referente ao Exército, ver a conferência de 30 de novembro de 1948 proferida na Escola do Estado Maior do Exército intitulada Nação e Exército, publicada depois em forma de livro. Nela, Freyre afirmou: "Força antidemocrática ou antipopular, o Exército nunca foi sistemática ou conscientemente entre nós. (...) A responsabilidade das Forças Armadas é, no Brasil de hoje, imensa porque no Brasil de hoje repita-se - pouco é o que se acha organizado e muita a desorganização" (FREYRE, 1965: 79). Com esse livro, Freyre explicitava mais uma vez o seu apoio ao golpe militar de 31 de março de 1964.

${ }^{18} \mathrm{E}$ importante ressalvar que a proposição freyriana de uma terceira via civilizacional, surgindo materialmente nos trópicos durante a Guerra Fria, estava distanciada, pela sua perspectiva notadamente cultural, dos nacionalismos políticos oriundos da Ásia e da África, organizados politicamente com a Conferência de Bandung, realizada na Indonésia em abril de 1955, com a presença de 29 países. Sobre Bandung, ver Saraiva (1997).

${ }^{19}$ Essa é uma evidente mistificação do autor, pois ao afirmar que o tempo da produção dos trópicos é mais moroso que o de regiões temperadas, o autor acaba por reendossar aquilo que sempre quis combater, o mito do atraso tropical determinado pelo clima. 
${ }^{20}$ Segundo Neto (1997: 342), "Salazar, o mesmo que habitualmente falava das 'raças inferiores' nos anos trinta, passou, como por magia, a paladino da 'sociedade pluriracial' (sic) exemplificada pelo Brasil-feitopelos-portugueses, com completa 'ausência de traços racistas', classificando Portugal [como uma] 'nação compósita, euro-africana e euro-asiática'".

21 Este magnífico trabalho circunstancia-se a analisar o primeiro volume dos discursos de Salazar, que se refere ao período de 1926 a 1942. Mas, para a observação que aqui faço, a questão cronológica é irrelevante.

${ }^{22}$ Note-se o tom de catástrofe do argumento. Aspecto que valida o raciocínio de José Gil.

${ }^{23}$ Convém ressaltar que Gilberto Freyre, ao contrário de Salazar, frente à URSS, tinha opiniões bem mais favoráveis, isto por acreditar que a URSS caracterizava-se como uma experiência positiva de democracia racial. Sobre a URSS e a democracia racial, conferir os comentários que apresentou no seu livro Aventura e Rotina.

${ }^{24}$ Utilizo uma enunciação que procura acompanhar a lógica freyriana de explicação do tempo tríbio.

25 A conferência apareceu publicada no ano seguinte. Ver Freyre (1960a); além da conferência, o autor publicou na mesma edição o trabalho Integração Portuguesa nos Trópicos, que escreveu sob encomenda para o governo Salazar, o qual foi distribuído a todos os corpos diplomáticos de Portugal, como peça de reforço e propaganda ideológica do regime.

${ }^{26}$ Quando Freyre esteve em Angola, em visita às instalações da companhia DIAMANG, manifestou sua contrariedade às práticas capitalistas, que quase nada tinham de "lusotropicais", desenvolvidas pela companhia na exploração dos trabalhadores angolanos. Freyre deixou seu protesto registrado no seu livro Aventura e Rotina. Sobre a DIAMANG e as práticas de sua administração em Angola, consultar Castro (1980).

${ }^{27}$ Sobre a questão das empresas denominadas "companhias majestáticas", mencionadas nesse parágrafo, consultar Telo (1994); sobre Armindo Monteiro, buscar outras informações em Rosas et al. (1996) e em Leonard (1998), especialmente nas páginas 85 e 164 desse último. ${ }^{28}$ Para uma definição de gestores como classe dominante capitalista consultar Bernardo $(1975,1991)$. 
${ }^{29}$ General Spínola, nesse seu famoso livro, diagnosticava assim a situação de Portugal naquela conjuntura de autonomias independentistas africanas: "Sem os territórios africanos, o País ficará reduzido a um canto sem expressão numa Europa que se agiganta, e sem trunfos potenciais para jogar em favor do seu valimento no concerto das Nações, acabando por ter uma existência meramente formal num quadro político em que a sua real independência ficará de todo comprometida" (SPÍNOLA, 1974: 226). Diante dessa constatação sugeria então a seguinte alternativa: "reformas necessárias em inequívoca expressão de uma autodeterminação africana pela soberania nacional; soberania que para ser autêntica, terá de ser exercida também pelos africanos" (SPÍNOLA, 1974: 233, grifos meus). Notar na expressão anterior, o limite sugerido da autodeterminação das independências coloniais portuguesas, naquela altura já em processo de radicalização. A ideia de Spínola, e de tantos outros (incluindo-se Sarmento Rodrigues e Gilberto Freyre) era a de que o processo de autonomia fosse realizado, mas controlado por Portugal. Para isso, ao final de seu livro, defendia uma "política de antecipação" controlada por Portugal a fim de se evitar qualquer "virulência" de "campanha anti-portuguesa" (SPÍNOLA, 1974: 235), por parte dos africanos.

${ }^{30} \mathrm{Na}$ vasta correspondência entre Sarmento Rodrigues e Gilberto Freyre mantida ao longo das décadas de 1950 e 1970, há uma carta remetida a Freyre, com data de 06 de junho de 1974, posterior, portanto, aos acontecimentos da Revolução dos Cravos. Na carta, Rodrigues descreve a situação política porque passava Portugal: "Quanto aos acontecimentos eu sou optimista. Por várias razões. Os dirigentes do Governo Provisório, da Junta de Salvação Nacional e do Regimento das Forças Armadas são em grande parte muito meus amigos. Alguns até íntimos. A começar pelo Presidente da República que me levantou um monumento na Guiné! Tenho-me avistado com muitos deles e até me têm honrado fazendo-me consultas. É boa gente e cheia de boas intenções. E parece-me que estão a ganhar firmeza. É claro que tem havido alguns exageros, sobretudo de palavriado (sic), mas isso é natural. É preciso ter confiança. Porque as intenções dos Governantes são as melhores". Essa carta pertence ao Arquivo Gilberto Freyre, da Fundação Gilberto Freyre, em Recife, Pernambuco. Os desdobramentos posteriores, com a independência, sobretudo de Angola, em 1975, derrubaram as perspectivas e anseios tecnocráticolusotropicais do senhor Sarmento Rodrigues.

Artigo recebido em 03/2009. Aprovado em 05/2009 